\title{
PEMBERIAN SCAFFOLDING PADA MATERI PENJUMLAHAN DAN PENGURANGAN PECAHAN BAGI SISWA SMP BERKEMAMPUAN MATEMATIKA RENDAH
}

\author{
Nur Oktaviani', Helti Lygia Mampouw ${ }^{2}$ \\ ${ }^{1,2}$ Pendidikan Matematika, Universitas Kristen Satya Wacana Salatiga, helti.mampouw@staff.uksw.edu
}

\section{INFO ARTIKEL}

Riwayat Artikel:

Diterima: 08-03-2018

Disetujui: 25-03-2018

\section{Kata Kunci:}

Scaffolding

Pecahan

Kesalahan Konseptual

Kesalahan Prosedural

\section{A. LATAR BELAKANG}

Pecahan adalah salah satu materi ajar dalam matematika yang banyak berguna dalam kehidupan sehari-hari. Menurut kurikulum 2013, materi pecahan sudah diajarkan sejak kelas III SD. Operasi hitung pada pecahan mulai dikenal siswa sejak kelas IV SD. Selanjutnya materi pecahan diaplikasikan misalnya dengan menghitung proporsi dan operasi hitung dalam berbagai aspek.

Pecahan biasanya terbedakan atas pecahan biasa dan pecahan campuran. Operasi hitung pada pecahan menjadi bagian dari kurikulum 2013 pada tingkat SMP/MTs. Yang dimaksud dengan operasi hitung adalah operasi hitung dasar yaitu penjumlahan, pengurangan, perkalian dan pembagian. Operasi hitung pada pecahan membutuhkan pemahaman konseptual dan prosedural. Misalnya, operasi hitung pada pecahan campuran dilakukan dengan terlebih dulu mengkonversi pecahan campuran ke bentuk pecahan biasa. Meskipun terlihat sederhana dan dipelajari secara sprial di SD dan SMP, operasi hitung pada pecahan tidak selalu dikuasai dengan baik oleh siswa.
Studi pendahuluan yang dilakukan di SMP Negeri 3 Cepogo pada kelas VII A dan hasil wawancara dengan guru mata pelajaran matematika menunjukkan ada masalah dalam penguasaan pecahan oleh siswa SMP. Kesalahan siswa sering terjadi pada saat mengubah pecahan campuran ke pecahan biasa dan kesalahan dalam mencari hasil operasi dua bilangan pecahan. Bukti kesalahan yang dilakukan oleh siswa yang berhasil direkam oleh Krista Pratanda Cahyanto W [1] ditampilkan pada gambar 1.

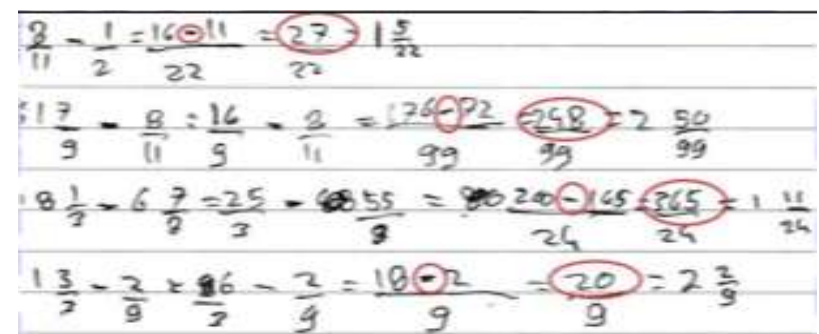

Gambar 1. bukti kesalahan siswa dalam mengerjakan soal pecahan

Pada gambar 1, nampak bahwa siswa sudah benar dalam menuliskan tanda operasi pengurangan, tetapi hasil operasi yang di dapat merupakan hasil penjumlahan. Dalam wawancara diperoleh bahwa siswa kurang teliti 
dalam membaca soal dan mengoperasikan bilangan pecahan.

Kesalahan yang terjadi pada saat melakukan operasi hitung pada pecahan harus diminimalisasi. Rahmawati melakukan penelusuran kesalahan untuk membantunya mengatasi permasalahan belajar siswa [2]. Salah satu upaya yang dapat dilakukan untuk meningkatkan pemahaman konsep siswa agar tidak mengulang kesalahannya yaitu dengan memberikan scaffolding [3].

Scaffolding berasal dari scaffold yang berarti tangga atau pijakan tukang batu ketika membangun tembok. Scaffolding merupakan istilah pada proses yang digunakan orang dewasa untuk menuntun anak-anak melalui zone of proximal development-nya. Sehingga scaffolding dapat diartikan sebagai bantuan yang disediakan teman yang lebih kompeten atau orang dewasa. Bantuan tersebut dapat berupa petunjuk, peringatan, dorongan, menguraikan masalah ke dalam langkah-langkah pembelajaran, memberikan contoh ataupun yang lain sehingga memungkinkan siswa tumbuh mandiri.

Anghileri mengusulkan tiga tingkatan dari scaffolding sebagai serangkaian dukungan dalam pembelajaran matematika [4]. Level paling dasar adalah enviromental provision. Pada level ini siswa didukunsg untuk belajar mandiri, scaffolding diberikan dengan guru menyiapkan lingkungan belajar siswa yang mendukung (classroom organization) misalkan dengan pengaturan kelompok, menyediakan lembar tugas secara terstruktur (structured task). Scaffolding pada level 1 tersebut ditunjukkan dengan gambar 2.

Pada level kedua terdapat interaksi langsung antara guru dan siswa. Bentuk interaksi meliputi menjelaskan (expalining) dengan cara untuk menyampaikan konsep yang dipelajari, meninjau (reviewing) dengan cara mengidentifikasi aspek-aspek yang paling penting berkaitan dengan implisit ide-ide matematika atau masalah yang akan dipecahkan, dan restrukturasi (restructuring) dengan cara menyederhanakan sesuatu yang abstrak dalam matematika menjadi lebih diterima oleh siswa. Dalam level ini guru dan siswa terlibat secara langsung dalam suatu interaksi, khususnya dalam matematika. Scaffolding pada level 2 tersebut ditunjukkan dengan gambar 3.

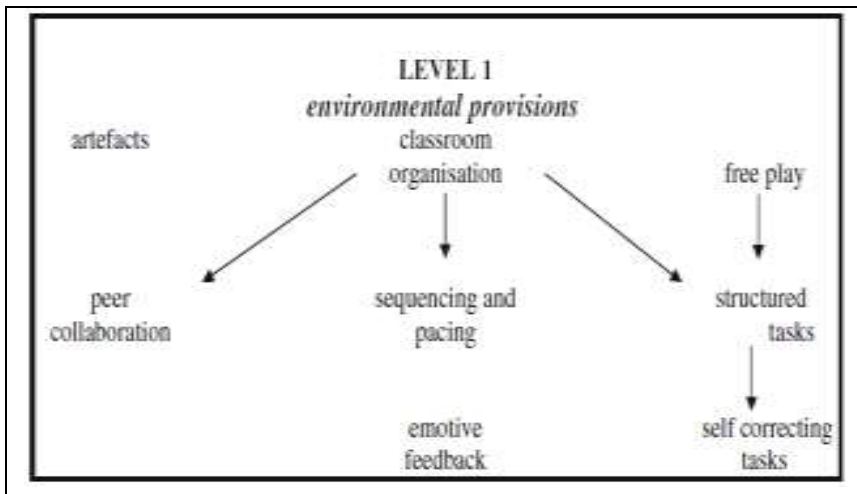

Gambar 2. Scaffolding Level 1 (Anghileri, 2006)

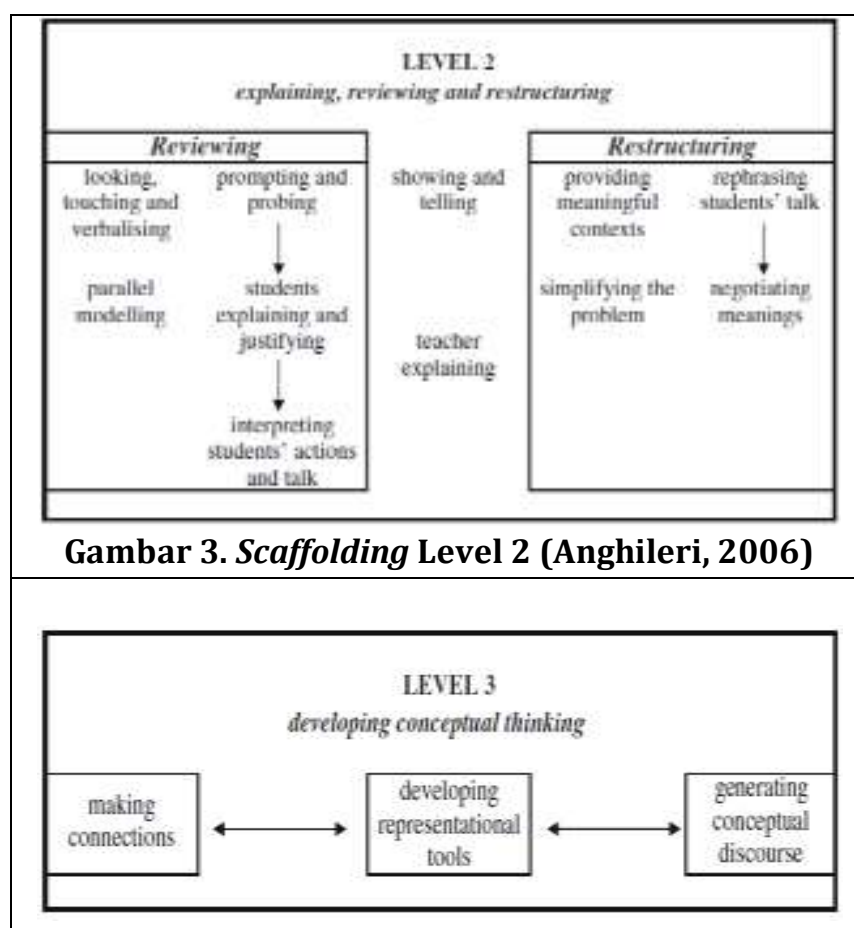

Gambar 4. Scaffolding Level 3 (Anghileri , 2006)

Level ketiga merupakan tingkatan tertinggi pada scaffolding level ini menuntut banyak kemampuan untuk mengulang prosedur yang telah dipelajari dalam menyelesaikan masalah. Level ini terdiri dari interaksi pengajaran yang secara gamblang mengembangkan pemikiran konseptual dengan menciptakan kesempatan untuk mengungkapkan pemahaman kepada siswa. Siswa didukung untuk membuat koneksi menggunakan alat-alat representasi dan dilibatkan dalam wacana konseptual yang dapat meningkatkan daya pikir. Scaffolding pada level 3 di tampilkan pada gambar 4 .

\section{B. METODE PENELITIAN}

Jenis penelitian ini adalah deskriptif kualitatif untuk mendeskripsikan hasil pemberian scaffolding materi operasi hitung pada pecahan untuk siswa SMP. Subjek terdiri dari 2 siswa kelas VII SMP Negeri 3 Cepogo yang berkemampuan matematika rendah dengan nilai tes kurang dari 35 pada rentang 0-100. Scaffolding diberikan kepada kedua siswa tersebut dengan mengacu pada tahapan scaffolding Anghileri yaitu Level 1 (Enviromental Provision), Level 2 (Explaining, Reviewing, Restructuring) dan Level 3 (Developing Conceptual Thinking). Instrumen utama yang digunakan dalam penelitian ini adalah peneliti sendiri dan instrumen pendukungnya adalah soal tes sebelum dan sesudah pemberian scaffolding dan pedoman wawancara. Data diperoleh melalui lembar jawaban subjek sebelum dan sesudah pemberian scaffolding dan wawancara bersamaan dengan proses scaffolding. 


\section{HASIL DAN PEMBAHASAN}

Hasil penelitian berupa deskripsi kesalahan siswa dalam mengerjakan soal penjumlahan dan pengurangan pecahan, deskripsi penerapan scaffolding untuk mengatasi kesalahan siswa dalam menyelesaikan soal materi operasi pecahan dan hasil setelah pemberian scaffolding. Pemberian soal penjumlahan dan pengurangan pecahan terhadap 34 siswa kelas VII A SMP N 3 Cepogo menghasilkan 202 kesalahan terbanyak ada pada soal nomor 6 yakni tentang pengurangan pecahan campuran dari pecahan biasa, di mana kesalahan di lakukan oleh 23 siswa. Deskripsi lebih lanjut tentang kesalahan Siswa berdasarkan jenis soal ditampilkan pada tabel 1 .

TABEL 1

KESALAHAN KONSEPTUAL DAN PROSEDURAL

\begin{tabular}{|c|c|c|c|}
\hline Jenis soal & $\begin{array}{c}\text { Kesalahan } \\
\text { konseptual }\end{array}$ & $\begin{array}{c}\text { Kesalahan } \\
\text { Prosedural }\end{array}$ & Total \\
\hline 1 & 6 & 8 & 14 \\
\hline 2 & 9 & 11 & 20 \\
\hline 3 & 8 & 10 & 18 \\
\hline 4 & 7 & 11 & 18 \\
\hline 5 & 5 & 12 & 17 \\
\hline 6 & 8 & 15 & 23 \\
\hline 7 & 6 & 13 & 19 \\
\hline 8 & 7 & 12 & 19 \\
\hline 9 & 8 & 13 & 21 \\
\hline 10 & 9 & 11 & 19 \\
\hline 11 & 6 & 8 & 14 \\
\hline Jumlah & 79 & 123 & 202 \\
\hline Presentase & $39,10 \%$ & $60,89 \%$ & $100 \%$ \\
\hline
\end{tabular}

Tabel 1 mengugkapkan bahwa terdapat 39,01\% kesalahan konseptual dan 60,89\% kesalahan prosedural. Kesalahan konseptual yang dilakukan misalnya siswa langsung menjumlahkan penyebut dan penyebut, pembilang dan pembilang. Kesalahan prosedural yang terjadi misalnya siswa mengetahui untuk menyamakan penyebut sebelum menjumlahkan pecahan tetapi siswa salah dalam melakukan perkalian. Jadi, dimungkinkan siswa melakukan kesalahan konseptual dan kesalahan prosedural pada soal yang sama. Oleh karena itu dimungkinkan pemberian scaffolding dilakukan untuk mengatasi kedua jenis kesalahan tersebut.

Deskripsi kesalahan 34 siswa yang ditampilkan pada tabel 1 menjadi dasar dalam penentuan subjek penelitian. Dipilih 2 siswa dengan kesalahan terbanyak sebagai subjek penelitian, yaitu RN dan KS. RN melakukan banyak kesalahan konseptual sedangkan KS melakukan kesalahan konseptual dan kesalahan prosedural yang hampir berimbang. Kesalahan konseptual dan kesalahan prosedural yang dilakukan oleh RN dan KS berturut-turut ditampilkan pada tabel 2 dan tabel 3. Tabel 2 memuat konsep-konsep di mana RN dan KS melakukan kesalahan konseptual. Tabel 3 memuat konsep-konsep di mana RN dan KS melakukan kesalahan prosedural.
TABEL 2.

KESALAHAN KONSEPTUAL RN DAN KS

\begin{tabular}{|l|c|c|}
\hline \multirow{2}{*}{$\begin{array}{c}\text { Konsep konsep yang } \\
\text { digunakan dalam pecahan }\end{array}$} & \multicolumn{2}{|c|}{$\begin{array}{c}\text { Kesalahan } \\
\text { Konseptual }\end{array}$} \\
\cline { 2 - 3 } & $\mathrm{RN}$ & $\mathrm{KS}$ \\
\hline 1. Menyamakan penyebutnya. & 4 & 8 \\
\hline $\begin{array}{c}\text { 2. Mengubah pecahan } \\
\text { campuran kepecahan biasa }\end{array}$ & $2,4^{*}$ & $2^{*}$ \\
\hline $\begin{array}{l}\text { 3. Mengubah soal cerita } \\
\text { kedalam bentuk matematika. }\end{array}$ & 11 & 4 \\
\hline $\begin{array}{l}\text { 4. Mengalikan pembilang } \\
\text { sesuai penyebut }\end{array}$ & 2,4 & $\begin{array}{c}1,2,3,4, \\
5,6,7^{*}, 8, \\
9,10\end{array}$ \\
\hline 5. Kesalahan notasi & $8,9,10^{*}$, & 4 \\
\hline
\end{tabular}

${ }^{*}=$ keragu - raguan subjek dalam menjawab.

TABEL 3.

KESALAHAN PROSEDURAL RN DAN KS

\begin{tabular}{|c|c|c|}
\hline \multirow{2}{*}{$\begin{array}{c}\text { Konsep konsep yang } \\
\text { digunakan dalam pecahan }\end{array}$} & \multicolumn{2}{|c|}{$\begin{array}{l}\text { Kesalahan } \\
\text { Prosedural }\end{array}$} \\
\hline & RN & KS \\
\hline $\begin{array}{ll}\text { 1. } & \text { Mengalikan pembilang } \\
\text { sesuai penyebut }\end{array}$ & 2,4 & $\begin{array}{l}1,2,3,4, \\
5,6,7,8, \\
9,10\end{array}$ \\
\hline 2. $\quad$ Kesalahan dalam perkalian & $\begin{array}{l}2,4,6, \\
7,8\end{array}$ & $1,2,5$ \\
\hline $\begin{array}{ll}\text { 3. } & \text { Kesalahan } \\
\text { penjumlahan }\end{array}$ & & \\
\hline $\begin{array}{lll}\text { 4. } & \begin{array}{l}\text { Kesalahan } \\
\text { pengurangan }\end{array} & \text { dalam } \\
\end{array}$ & 5,9 & \\
\hline $\begin{array}{ll}\text { 5. Kesalahan dalam } \\
\text { menentukan hasil ahir }\end{array}$ & $\begin{array}{l}2,4,5, \\
6,7,9, \\
10^{*}, 11\end{array}$ & $\begin{array}{l}1,2,3,4, \\
5,6,7,8, \\
9,10\end{array}$ \\
\hline
\end{tabular}

*= keragu - raguan subjek dalam menjawab.

\section{Deskripsi pemberian scaffolding kepada RN}

Hasil pekerjaan RN soal nomor 4 pada gambar 5 terlihat bahwa subjek mengerjakan soal tidak menggunakan konsep penjumlahan pecahan dimana seharusnya pecahan campuran diubah kedalam bentuk pecahan biasa terlebih dahulu. Kesalahan RN pada nomor 4 tergolong kesalahan konseptual. Scaffolding yang diberikan RN berada pada level 2, yaitu tahap reviewing, explaining, dan restructuring. Scaffolding yang digunakan pada tahap reviewing yaitu melihat kembali jawaban yang telah RN tuliskan untuk mengetahui metode yang digunakan subjek dalam menngerjakan soal nomor 4 . Ternyata RN tidak memahami metode untuk menyelesaikan soal cerita penjumlahan pecahan metode yang RN gunakan salah yaitu RN tidak mengubah pecahan campuran ke bentuk pecahan biasa dulu, RN juga melaukan kesalahan dalam menyamakan penyebut RN sama sekali tidak menyamakan penyebut.

RN tidak menguasai konsep yang digunakan untuk mengerjakan soal cerita operasi hitung penjumlahan pecahan, maka scaffolding yang digunakan yaitu tahap explaining. Pada tahap explaining peneliti meminta RN 
untuk membaca soal Rara memiliki $2 \frac{2}{7}$ meter pita, kemudian Toni memberi $\frac{1}{6}$ meter pita. Berapa meter pita Rara sekarang. Peneliti menanyakan kepada subjek bila ada kata kata memberi berarti diapakan RN menjawab dijumlahkan. Peneliti bertanya $2 \frac{2}{7}$ ini masih dalam bentuk pecahan apa subnek RN menjawab campuran lalau diapakan RN menjawab dikalikan 2 x 7+2 jadi hasilnya 16 . 16 perberapa $\frac{16}{7}+\frac{1}{6}$, lalau penyebutnya belum sama harus diapakam RN menjawab dengan benar dengan cara KPK .kemudian KPK dari 7 dan 6 berapa RN menjawab 42.

Proses restructuring yang diberikan yaitu dengan memberikan pertanyaan arahan untuk membantu RN memahami konsep dan mengerjakan soal dengan benar sekarang bagaimana caramu mengerjakan soal no 4 . Subjek NB menjawab 16 dikaikan 6 dan 1 dikalikan 7 alau hasilnya gimana subjek NB menjawab $\frac{96}{42}+\frac{7}{42}=\frac{103}{42}$. Terlihat pada gambar 7 dan 8 bahwa RN telah mengerjakan soal tambahan dengan benar, sehingga proses scaffolding dianggap sudah cukup.

\begin{tabular}{|c|c|}
\hline 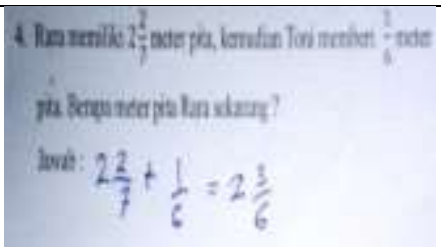 & 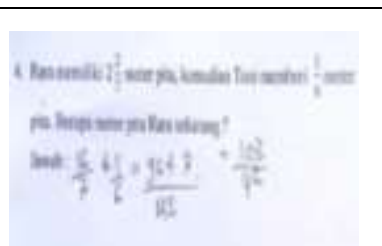 \\
\hline $\begin{array}{c}\text { Gambar 5. Contoh Kesalahan } \\
\text { konseptual Pada RN Soal } \\
\text { Nomor } 4\end{array}$ & $\begin{array}{c}\text { Gambar 6. Hasil } \\
\text { Pekerjaan RN Setelah } \\
\text { Pemberian scaffolding }\end{array}$ \\
\hline 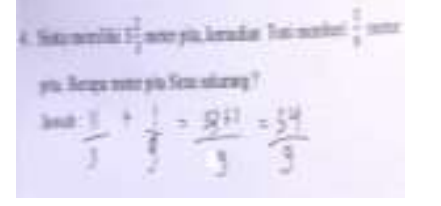 & 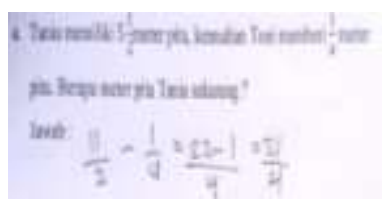 \\
\hline $\begin{array}{c}\text { Gambar 7. Hasil Pekerjaan } \\
\text { Tambahan RN }\end{array}$ & $\begin{array}{c}\text { Gambar 8. Hasil } \\
\text { Pekerjaan Tambahan RN }\end{array}$ \\
\hline
\end{tabular}

\section{Deskripsi pemberian scaffolding kepada KS}

Hasil pekerjaan KS soal nomor 6 pada gambar 9 terlihat bahwa subjek mengerjakan soal sudah menggunakan konsep pecahan campuran dimana pecahan cmpuran diubah kedalam bentuk pecahan biasa terlebih dahulu tetapi sunjek melakukan kesalahan dalam perhitungan. Kesalahan KS pada nomor 6 tergolong kesalahan konseptual dan prosedural. Scaffolding yang diberikan KS berada pada level 2, yaitu tahap reviewing, explaining, dan restructuring. Scaffolding yang digunakan pada tahap reviewing yaitu melihat kembali jawaban yang telah KS tulsikan untuk mengetahui metode yang digunakan subjek dalam menngerjakan soal nomor 6 . Ternyata KS tidak memahami metode untuk menyelesaikan pengurangan pecahan metode yang KS gunakan salah yaitu KS tidak mengubah pecahan campuran ke bentuk pecahan biasa dulu, KS sudah menyamakan penyebut dengan benar tetapi dalam mengalikan pembilangya sesuai dengan yang dikalikan penyebut masih melakukan kesalahan.

KS tidak menguasai konsep yang digunakan untuk mengerjakan operasi hitung pengurangan pecahan, maka scaffolding yang digunakan yaitu tahap explaining. Pada tahap explaining peneliti meminta KS Kemudian peneliti memancing kalau kedua pecahan campuran harus diubah dulu kedalam bentuk pecahan apa KS menjawab diubah dulu kedalam bentuk pecahan bisa kemudian selanjutnya diapakan KS menjawab disamakan penyebut ok kalau setelah disamakan penyebut hasilnya berapa KS menjawab 99. Berarti 9 dikalikan 11 dan 16 ya dikalikan berapa KS menjawab 9 jadi hasilnya 172 dan yang 11 dikalikan 9 berarti yang 8 bagaimana KS menjawab dikalikan 9 lalau hasilnya 72.

Proses restructuring yang diberikan yaitu dengan memberikan pertanyaan arahan untuk membantu KS memahami konsep dan mengerjakan soal dengan benar sekarang bagaimana caramu mengerjakan soal no $6 \mathrm{KS}$ menjawab $\frac{176}{99}-\frac{72}{99}$ oke sekarang penyebutya udah sama lalau diapakan KS mejawab dikurangkan dan hasilnya $\frac{104}{99}$. Terlihat pada gambar 14 dan 15 bahwa KS telah mengerjakan soal tambahan dengan benar, sehingga proses scaffolding dianggap sudah cukup.

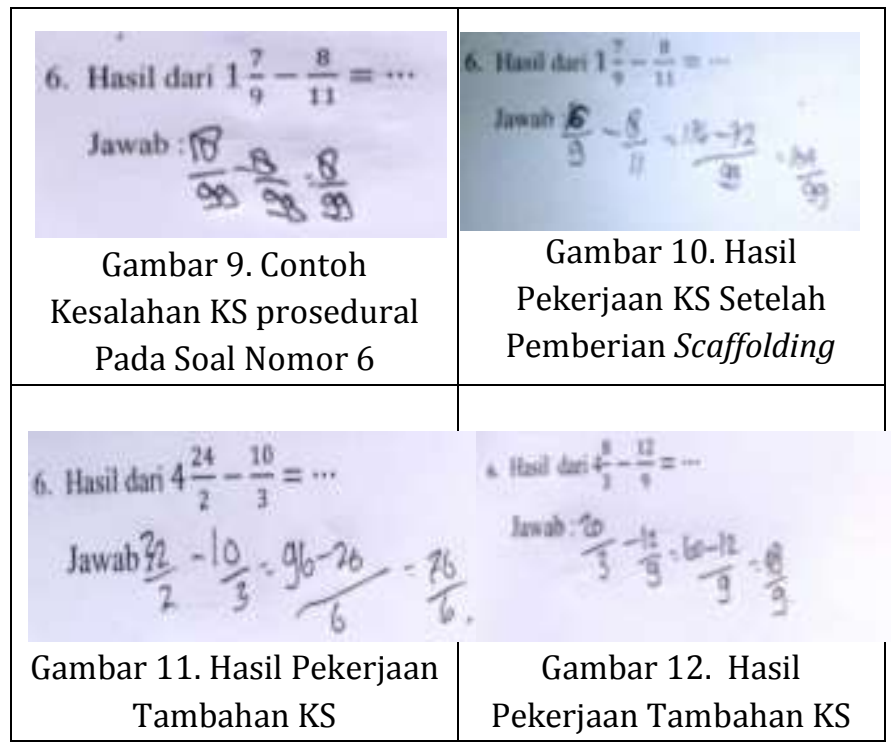

\section{Rangkuman pemberian Scaffolding pada setiap kesalahan}

Dari analisis tipe kesalahan dan pemberian scaffolding yang telah dilakukan, dibuat rangkuman pemberian scaffolding pada tiap tipe kesalahan yang ditampilkan pada tabel 4. Pemberian scaffolding baik tipe kesalahan konseptual dan prosedural untuk RN dan KS berada pada level 2 karena level 1 telah dipenuhi. Setelah pemberian scaffolding level 2 kedua subjek penelitian telah menunjukan hasil yang baik. Oleh karena itu level 3 tidak perlu diberikan. Meskipun pemberian scaffolding pada 
kedua tipe kesalahan berada pada level 2 namun kesaalahan prosedural tidak memerlukan explaining.

\section{TABEL 4}

PEMBERIAN SCAFFOLDING TIAP TIPE KESALAHAN

\begin{tabular}{l|ll}
\hline Tipe Kesalahan & \multicolumn{4}{l}{ Scaffolding yang diberikan } \\
\hline Kesalahan & Tahap reviewing, explaining dan
\end{tabular}

Konseptual restructuring

Meneliti kembali hasil pekerjaan (reviewing), membantu subjek untuk memhami konsep dengan menjelaskan konsep dengan benar (explaining) dan membangun pemahaman ulang apabila subjek tidak memahami konsep (restructuring).

Kesalahan $\quad$ Tahap reviewing dan restructuring

Prosedural Meminta subjek untuk meneliti kembali hasil pekerjaannya (reviewing) dan membangun pemahaman ulang jika subjek tidak memahami konsep (restructuring).

\section{TEMUAN}

Temuan penelitian pada RN yaitu RN tidak memahami konsep operasi hitung pada soal cerita pecahan dimana seharusnya pecahan campuran harus diubah dulu kedalam pecahan biasa, sehingga RN banyak melakukan kesalahan dalam mengerjakan soal terkait materi operasi hitung pada soal cerita pecahan.

Temuan penelitian pada KS yaitu KS memahami konsep operasi hitung pada soal pengurangan pecahan dimana pecahan campuran harus diubah dulu kedalam pecahan biasa tetapi melakukan kesalahan dalm penghitungan, sehingga KS banyak melakukan kesalahan dalam mengerjakan soal terkait materi operasi hitung pada soal pengurangan pecahan.

\section{E. SIMPULAN DAN SARAN}

Berdasarkan hasil penelitian mengenai deskripsi pemberian scaffolding pada materi penjumlahan dan pengurangan pecahan bagi siswa SMP berkemampuan matematika rendah, kesalahan-kesalahan digolongkan atas kesalahan konseptual dan kesalahan prosedural. Kesalahan yang paling banyak dilakukan oleh subjek adalah prosedural dengan presentase $60,89 \%$.

Berdasarkan penelitian yang telah dilakukan subjek RN banyak melakukan kesalahan konseptual di mana RN mengalami kesalahan terutama dalam menghitung, misalnya mengubah pecahan campuran ke pecahan biasa menentukan hasil akhir. KS melakukan kesalahan yang banyaknya cenderung seimbang antara kesalahan konseptual dan prosedural. KS melakukan kesalahan konseptual maupun prosedural dalam menyamakan pembilang pada penyebut yang telah diperoleh, sekaligus melakukan kesalahan dalam menghitung. Pemberian scaffolding dilakukan berdasarkan kesalahan siswa meliputi scaffolding pada level 2 yaitu reviewing, explaining dan restructuring yang sesuai dengan kesalahan kedua subjek. Penerapan scaffolding dapat membantu untuk mengatasi kesalahan dalam menyelesaikan soal pada materi operasi hitung penjumlahan dan pengurangan pecahan. Bentuk scaffolding yang diberikan berada pada level 2. Pada kesalahan konseptual bentuk scaffolding yang diberikan adalah dengan meneliti kembali hasil pekerjaan (reviewing), membantu subjek untuk memhami konsep dengan menjelaskan konsep dengan benar (explaining) dan membangun pemahaman ulang apabila subjek tidak memahami konsep (restructuring). Pada Kesalahan prosedural bentuk scaffolding yang diberikan adalah dengan meminta subjek untuk meneliti kembali hasil pekerjaannya (reviewing) dan membangun pemahaman ulang jika subjek tidak memahami konsep (restructuring). Pada kesalahan konseptual dan kesalahan prosedural yang berimbang, bentuk scaffolding yang diberikan sama seperti pemberian scaffolding yang diberikan kepada subjek yang banyak melakukan kesalahan konseptual.

Setelah pemberian scaffolding yang sesuai dengan kesalahannya, kedua subjek memahami konsep pecahan dan dapat menyelesaikanya. Berdasarkan hasil penelitian ini pemberian scaffolding dapat dilakukan untuk mengatasi kesalahan siswa. Sebaiknya guru melakukan penelusuran kesalahan siswa sebagai upaya untuk memilih scaffolding yang tepat supaya guru dapat membatu siswa mengatasi kesalahan dan meningkatkan hasil belajar siswa.

\section{UCAPAN TERIMA KASIH}

Disampaikan kepada keluarga besar SMP N 3 Cepogo dan Pusat Studi Pendidikan Sains, Teknologi dan Matematika UKSW atas bantuan yang diberikan.

\section{DAFTAR RUJUKAN}

[1] Krista Pratanda Cahyanto W; (2012). Analisis Tipe Kesalahan Siswa Dan Pemberian Scaffolding Dalam Menyelesaikan Soal Materi Operasi Bilangan Pecahan Kelas VIIC SMP Kristen Satya Wacana Salatiga. Skripsi. UKS Salatiga.

[2] Ambarwati, D. J. (2014). Analisis Kesalahan Siswa menurut Kastolan dalam Menyelesaikan Soal Matematika Pokok Bahasan Operasi Bilangan Berpangkat dan Bentuk Akar pada Siswa Kelas X SMK PGRI 2 Salatiga Tahun 2013/2014. Skripsi. UKSW Salatiga.

[3] Sahriah, Siti 2012 Analisis Kesalahan Siswa Dalam Menyelesaikan Soal Matematika Materi Operasi Pecahan Bentuk Aljabar Kelas VII SMP N 2 Malang

[4] Anghileri, J. (2006). Scaffolding Practices That Enhance Mathematics Learning. Journal of Mathematics Teacher Education (2006), 33-52. 